\title{
Indicator minerals as guides to base metal sulphide mineralisation in Betul Belt, central India
}

\author{
Biswajit Ghosh ${ }^{1, *}$ and M N Praveen ${ }^{2}$ \\ ${ }^{1}$ Geological Survey of India, Operation: WB-SK-AN, Bhu Bijnan Bhawan, DK-6, Sector-II, \\ Salt Lake, Kolkata 700 091, India. \\ ${ }^{2}$ Geological Survey of India, Operation: TNPK, Kerala Unit, Dharani Bhawan, \\ Manikanteshwaram, Thiruvananthapuram 695 013, India. \\ *e-mail: bghosh_geol@hotmail.com
}

\begin{abstract}
Zn-bearing minerals that act as indicator minerals for base metal sulphide mineralization from the Proterozoic Betul Belt, central India with special emphasis on their genetic significance have been discussed. Sulphide mineralisation is hosted by the felsic volcanic rocks and has similarities with volcanic-hosted massive sulphide deposits in other parts of the world. Synvolcanic hydrothermal alteration is crudely zoned with an inner high $\mathrm{Mg}$-Ca core and an outer wider envelop of $\mathrm{Al}-\mathrm{Fe}$ rich mineral assemblage. Most of the prospects have strata bound, moderately to steeply dipping, multiple, sub-parallel sheet like ore bodies composed of disseminated and semi-massive to massive ores. Zn-bearing spinel, staurolite, biotite and ilmenite typically occur within the foot-wall alteration zones in close proximity to the sulphide mineralization. Zincian spinel is ubiquitous irrespective of the nature of alteration zone. Zincian staurolite is nearly absent in Mg-Ca alteration zones but commonly present in Al-Fe alteration zone along with zincian ilmenite. Zn-bearing biotite in intimate association with zincian spinel is generally found in $\mathrm{Mg}$-Ca alteration zone and in the transition to $\mathrm{Al}-\mathrm{Fe}$ alteration zone. Most of these indicator minerals can be considered as products of desulphidation of sphalerite during metamorphism. Mechanisms other than desulphidation like formation of gahnite by overstepping of the zinc saturation limit of biotite during retrogression to chlorite and formation of zincian staurolite at the expense of gahnite is also recorded. Field presence of these minerals has immense significance in exploration in Betul Belt as they occur in close spatial relationship with the sulphide rich zones and therefore act as direct vectors to ore.
\end{abstract}

\section{Introduction}

Indicator minerals are mineral species that, being mechanically and chemically resistant to weathering when found in clastic sediments, indicate the presence of a specific type of mineralization in bedrock (McClenaghan 2005). Their physical and chemical characteristics, including a relatively high density, facilitate their preservation and identification and allow them to be readily recovered from sample media such as till, stream sediments or soil, saprolite float and even in gossan. Indicator minerals have become an important exploration method in the past 20 years and now include suites for detecting a variety of ore deposit types including diamond, gold, $\mathrm{Ni}-\mathrm{Cu}$, PGE, porphyry $\mathrm{Cu}$, massive sulphide and tungsten deposits.

Investigation for base metal sulphide mineralisation, particularly for zinc has been carried out by Geological Survey of India in different prospects of the Betul Belt such as Bhawra-Tekra, BargaonTarora, Kehalpur, Chopna-Munrai, BanskhapaPipariya, Ghisi, Muariya, Koparpani, Dehalwara and Bhuyari. Presence of gahnite $\left(\mathrm{ZnAl}_{2} \mathrm{O}_{4}\right)$ or zincian spinel in the bedrock, soil or stream sediments is considered to be an important indicator

Keywords. Gahnite, zincian staurolite; ecandrewsite; hydrothermal alteration; Betul Belt; indicator minerals. 


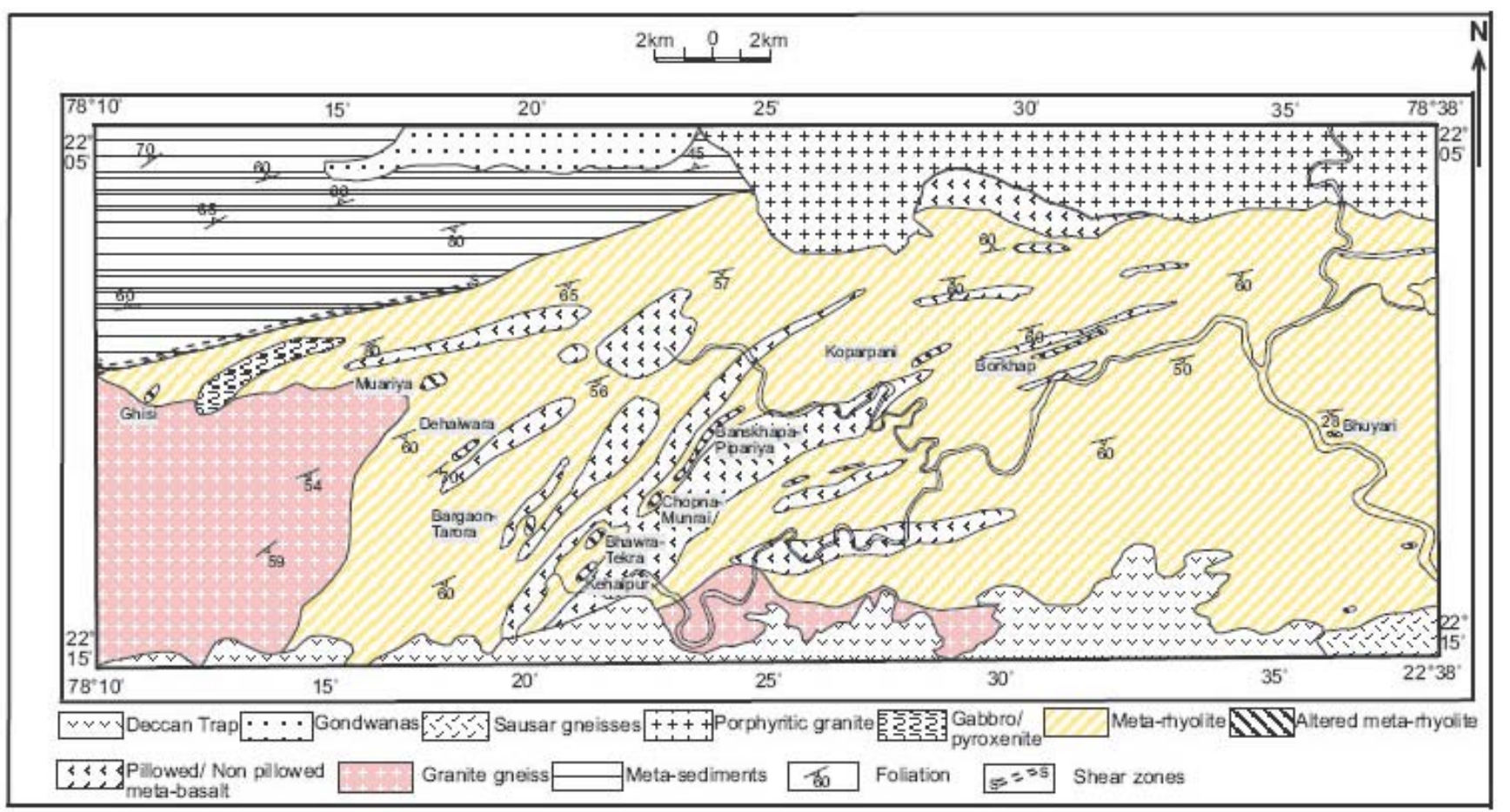

Figure 1. Geological map of the central part of the Betul Belt showing different areas of base metal mineralization.

for the proximity to zinc mineralization and has been successfully used in the past to locate new areas with sulphide mineralization. Zincian spinel is reported from metamorphosed hydrothermally altered felsic volcanic rock from Muariya, Banskhapa, Koparpani and Bhuyari prospects (Mahakud et al 2001; Ghosh et al 2006; Praveen and Ghosh 2007). Recently, Ghosh and Praveen (2007) added new data from Koparpani base metal prospect of this belt.

With the use of in situ microbeam techniques other minerals like zincian staurolite, Znbearing biotite and zincian ilmenite can be used as indicator minerals to locate zinc mineralization. Although minerals like staurolite, biotite and ilmenite are widespread in the alteration zones of Betul Belt, Zn-bearing staurolite, biotite and ilmenite typically occur within the alteration zones in close proximity to the sulphide-rich zones as documented by Praveen and Ghosh (2007) and Ghosh and Praveen (2007).

The identification of Zn-rich minerals has major significance in exploration in Betul Belt as they occur in close spatial relationship with the sulphide rich zones and therefore act as direct vectors to ore. The present contribution was prompted by the invariable presence of one or all of these minerals within or adjacent to the sulphide rich zones in all the prospects of Betul Belt and it discusses their importance with special emphasis on their genetic significance.

\section{Geology of Betul Belt}

The Proterozoic Betul Belt forms a conspicuous lithotectonic unit of the Central Indian Tectonic Zone (CITZ) between Mahakoshal Belt in the north and Sausar Belt in the south. Quartzite, meta-pelite, bimodal volcanic rocks (basaltrhyolite), meta-exhalites, calc silicate rocks and banded iron formation constitute the supracrustal rocks of this belt. The belt is traversed by several ENE-WSW trending ductile shear zones having sub-vertical to steep dips, which were developed during deformation (Roy and Prasad 2001, 2003). The Betul Belt represents a unique litho-package in the CITZ comprising a prominent bimodal volcanic sequence in which felsic volcanic rocks are dominant (figure 1). Sulphide mineralisation is hosted by the felsic volcanic rocks and has similarities with volcanic-hosted massive sulphide deposits (VHMS) in other parts of the world.

Bimodal volcanics in the region consist of both meta-basalt and meta-rhyolite. Mafic volcanics occur as elongate lenses and often show interfingering relationship with the felsic volcanics. They consist of pillowed and non-pillowed metabasalts with associated mafic volcaniclastics and cherts. Felsic volcanics are represented by rhyolites, rhyolitic volcaniclastics and cherts. In mineralised areas, syngenetic hydrothermal alteration and subsequent metamorphism has obliterated primary volcanic textures in most of the rocks, however 
relatively unaltered rocks display relict textural features based on which different volcanic facies could be recognised. The most abundant felsic volcanic facies are massive rhyolite and felsic volcaniclastics. Minor bands of laminated tuffs and chert also occur within the felsic volcanics. Massive rhyolite is generally quartz-porphyritic with rounded quartz phenocrysts in a recrystallised quartzo-feldspathic groundmass. Rhyolites at places show flow banding defined by alternate $\mathrm{mm}-\mathrm{cm}$ scale pale siliceous bands and darker phyllosilicate rich bands. Volcaniclastics generally contain angular to rounded clasts in a finer grained recrystallised quartzo-feldspathic groundmass. Clasts are composed of rhyolite fragments or quartz and range in size from lapilli to bombs. Felsic volcaniclastics appear to be the favourable host rock for mineralization in most prospects. Volcaniclastic facies comprising of coarse (lapilli to bomb sized) rhyolite fragments form host rock for mineralization at Muariya prospect. Similar coarse felsic volcaniclastics form the host rocks in Bhanskapa-Pipariya and Bhanwara-Tekra prospects. At Dehalwara and Koparpani, mineralization occurs within felsic volcaniclastics that contain lapilli sized clasts. In many of these areas volcaniclastic rocks lie adjacent to massive, quartz-porphyritic rhyolite. However at Bhuyari prospect, mineralization is hosted by massive quartz-porphyritic rhyolite which at places preserves flow banding. A regional ENE-WSW to E-W trending schistosity with moderate southerly dips is developed in most of the rocks which is subparallel to the contact between the felsic and mafic volcanics.

\subsection{Hydrothermal alteration}

Most VHMS deposits are characterized by distinct hydrothermal alteration zones that underlie them and these are produced by reaction of ore forming fluid with the foot-wall rocks. Two major styles of foot-wall alteration are: foot-wall alteration pipes which exists immediately below the massive sulphides and conformable, strata-bound alteration which is regionally extensive. Alteration pipes are commonly zoned with an inner chloritic core and an outer sericitic zone or an inner quartz-sericite core with an outer chlorite rich zone (Franklin et al 1981). Riverin and Hodgson (1980) noted that the mineralogical zonation is accompanied by chemical changes with greatly increased $\mathrm{MgO}$ and $\mathrm{FeO}$ in the chloritic core and increased $\mathrm{K}_{2} \mathrm{O}$ in the sericite zones and pervasive loss of $\mathrm{Na}_{2} \mathrm{O}$ in all the zones.

A striking feature of the felsic volcanics in the Betul Belt is the presence of intensely altered rocks near the ore zones that show near total destruction of volcanic textures as a result of development of various assemblages of metamorphic minerals. Intensely altered felsic volcanics hosting the ore zones grade laterally into moderately altered and further into unaltered rhyolites. Alteration is generally more extensive towards one side of the ore bodies, which is therefore interpreted as the stratigraphic foot-wall through which ascending hydrothermal fluids circulated prior to tilting of the strata. Well defined alteration pipes are not observed, more commonly alteration is strata-bound with alteration assemblages occurring conformably along the ore zones and towards their foot-wall side. Alteration is vaguely zoned with an inner high $\mathrm{Mg}-\mathrm{Ca}$ core represented by mineral assemblages with anthophyllite + actinolite + phlogophite + chlorite + garnet + gahnite and an outer wider envelop of $\mathrm{Al}-\mathrm{Fe}$ rich mineral assemblage with quartz + garnet + staurolite + sillimanite + gahnite + sericite . Within the Mg-Ca alteration zone, small, irregular pockets of carbonate bearing rocks represented by an assemblage containing tremolite, dolomite, talc and chlorite are present in many prospects. Praveen et al (2005) showed that the high $\mathrm{Mg}$ rocks are also depleted in $\mathrm{Na}$ and $\mathrm{K}$; they suggested that the $\mathrm{Mg}-\mathrm{Ca}$ rich assemblages and $\mathrm{Al}-\mathrm{Fe}$ rich assemblages associated with the ore zones in the Betul Belt might correspond to amphibolite grade equivalents of chlorite rich and sericite rich parts of the hydrothermally altered protolith. The pockets of tremolite-dolomite bearing rocks could be metamorphosed hydrothermal carbonatechlorite-quartz zones. At Bhuyari, outcrops of tremolite-carbonate rocks are closely associated with sulphide-rich zones and these at places exhibit relict primary laminations which suggest that they could be meta-exhalites related to a mineralizing hydrothermal vent (Praveen and Ghosh 2007). The area has been metamorphosed to staurolitealmandine grade (Mahakud et al 2001). Ghosh et al (2003) proposed two phases of metamorphism in which the first event is a prograde one followed by a retrograde metamorphism which might have been caused due to exhumation.

\subsection{Sulphide mineralization}

Sulphide deposits in the Betul Belt define a spectrum from $\mathrm{Zn}-\mathrm{Cu}$ type to $\mathrm{Zn}-\mathrm{Pb}-\mathrm{Cu}$ type. Metal ratios of the prospects may be related to the composition of the foot-wall volcanics (Praveen et al 2007). $\mathrm{Zn}-\mathrm{Pb}-\mathrm{Cu}$ prospects of Muariya, Ghisi, Bhuyari and Dehalwara are located in areas where felsic volcanic rocks are dominant over mafic volcanics whereas $\mathrm{Zn}-\mathrm{Cu}$ prospects like Banskhapa-Pipariya, Bhanwra-Tekra, and Bargaon-Tarora occur in very thin sequences of 


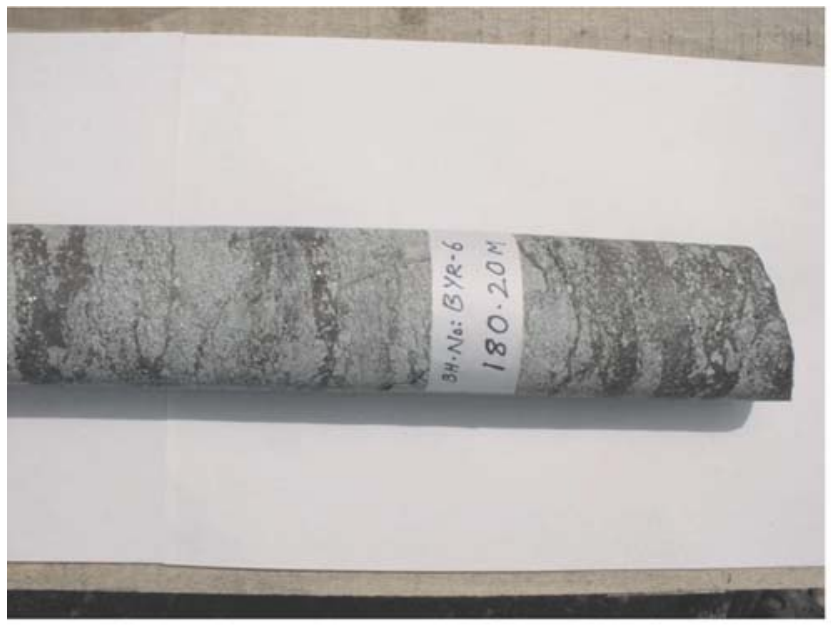

(A)

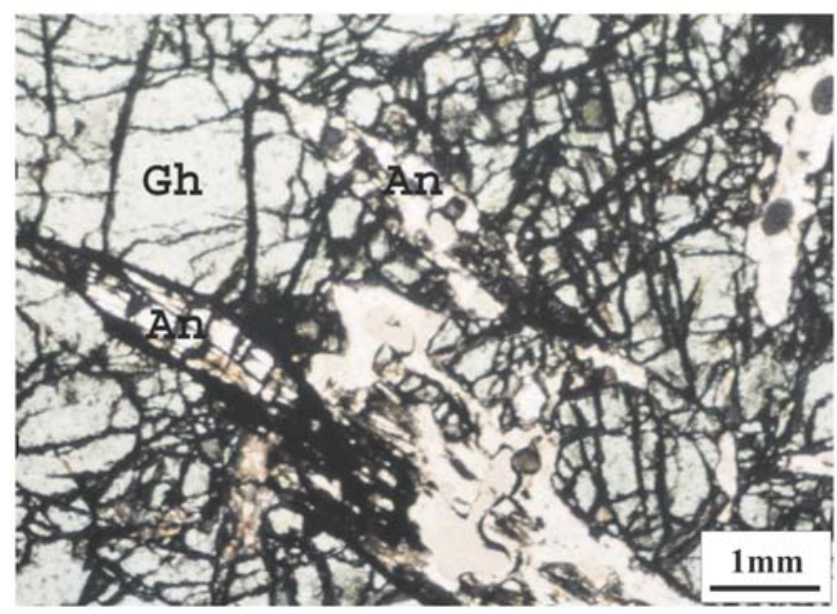

(C)

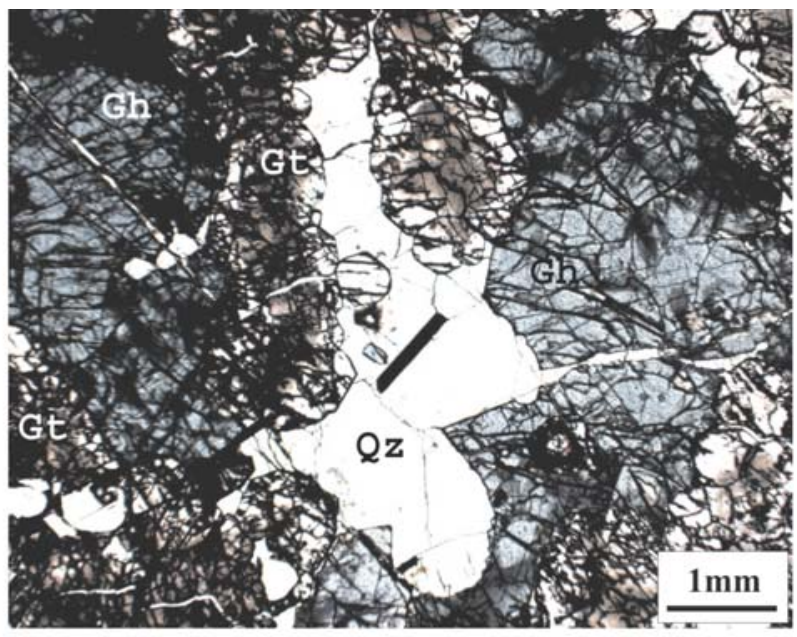

(B)

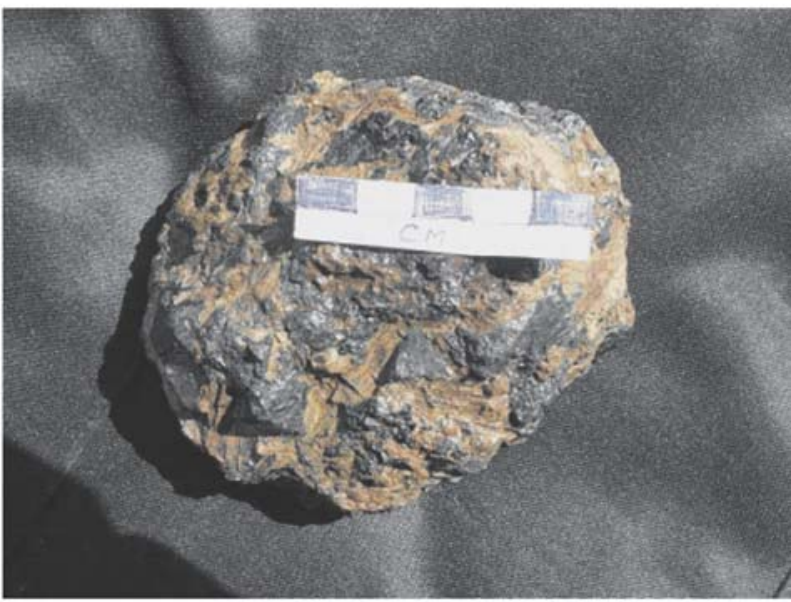

(D)

Figure 2. (A) Drill core showing multiple sheet like semi-massive ore zones from Bhuyari prospect; (B) Gahnite (Gh) in association with garnet (Gt) and quartz (Qz) from the Fe-Al alteration zone of Banskhapa prospect; (C) Gahnite-anthophyllite (An) association from the Mg-Ca alteration zone of the same prospect; (D) Hand specimen of the gahnite-anthophyllite rock showing idiomorphic crystals of gahnite (dark, elevated) in association with anthophylite.

felsic volcanics enclosed within more voluminous mafic volcanics.

The mineralised horizons consist of mainly disseminated ore, which enclose sub-parallel lenses of massive ( $>50$ vol \% sulphide minerals) and semi-massive (25-50 vol \% sulphide minerals) ore. Zinc is the major metal with subordinate $\mathrm{Pb}$ and $\mathrm{Cu} . \mathrm{Ag}$ and $\mathrm{Cd}$ are the other associated metals. The ore zones are enveloped by a halo of disseminated pyrite extending 100 to 200 meter into the foot-wall and up to 50 meter towards the hangingwall. Disseminated pyrrhotite occurs along with pyrite and minor chalcopyrite below the ore zones. Pyrrhotite and pyrite occur in the massive as well as in disseminated ore.

Most of the prospects have strata bound, moderately to steeply dipping, multiple, sub-parallel sheet like ore bodies composed of disseminated and semi-massive to massive ores (figure $2 \mathrm{~A}$ ).
At Banskhapa-Pipariya, Mahakud et al (2002) noted that within the sub-parallel ore bodies there exists a distinct vertical metal zonation with the upper ore bodies being zinc rich and the lower ore bodies being more copper rich. Sulphide mineralogy consists of mainly sphalerite, pyrite, galena, chalcopyrite and pyrrhotite. Major gangue minerals comprise of quartz, chlorite, biotite, amphibole, garnet and gahnite. No primary lamination or bedding is observed in the sulphides. Ore textures are indicative of metamorphic recrystallisation and massive sulphides have medium-to-coarse grained sphalerite-galenachalcopyrite-pyrite assemblages. Chalcopyrite disease textures with blebby inclusions of chalcopyrite within sphalerite are a common feature (Praveen et al 2007). In semi-massive portions, sulphides occupy intergranular spaces of the host rock minerals. Relict host rock patches are commonly 
present within the massive sulphides. Such features commonly occur in massive sulphides within volcaniclastics and are related to a sub-seafloor replacement origin for the ores as ore fluids rise through permeable rocks (Doyle and Allen 2003).

\section{Indicator minerals}

The use of microbeam techniques to study the chemistry of the alteration minerals have resulted in the identification of several Zn-bearing minerals other than gahnite like zincian staurolite, zincian ilmenite and Zn-bearing biotite. One or more of these minerals have been identified from the alteration zones of each of the prospects at Koparpani, Muariya, Dehalwara, BhanskapaPipariya and Bhuyari. Formation of these minerals is controlled by a variety of physical and chemical parameters including $\mathrm{f}\left(\mathrm{O}_{2}\right), \mathrm{f}\left(\mathrm{S}_{2}\right)$, pressure, temperature, composition of the host rock and ability of these minerals other than spinel to incorporate $\mathrm{Zn}$ in their structure. As a result, zincian staurolite is nearly absent in $\mathrm{Mg}$-Ca alteration zones but commonly present in Al-Fe alteration zone. Zincian spinel, on the other hand, is ubiquitous irrespective of the nature of alteration zone. Zn-bearing biotite along with zincian spinel is generally found in $\mathrm{Mg}$-Ca alteration zone and in the transition to Al-Fe alteration zone. Zincian ilmenite occurs in $\mathrm{Al}-\mathrm{Fe}$ alteration zone of Koparpani prospect (figure 1). Zincian ilmenite with $\mathrm{Fe}+\mathrm{Mn}<0.5$ apfu (known as ecandrewsite) is extremely rare, only reported from Al-Fe alteration zone of Koparpani area (Ghosh and Praveen 2007). The present study reports zincian ilmenite (with $\mathrm{Zn}<0.5 \mathrm{apfu}$ ) from Banskhapa and Dehalwara prospect of the Betul Belt (figure 1).

\subsection{Zincian spinel}

Zincian spinel or gahnite $\left[(\mathrm{Zn}, \mathrm{Fe}, \mathrm{Mg}) \mathrm{Al}_{2} \mathrm{O}_{4}\right]$ is an accessory mineral found in various geologic settings including metamorphosed massive sulphide deposits, aluminous metasediments, pegmatites, skarns and marbles. Although not that abundant in nature, it is most common in and around metamorphosed massive sulphide deposits (MMS). In view of the spatial relation between zincian spinel and metamorphosed volcanogenic base metal sulphide mineralisation, and based on compositional considerations, zincian spinel has been proposed as an indicator mineral and a potential exploration guide in the search of ores of this type (Sandhaus and Craig 1986; Sheridan and Raymond 1984; Spry and Scott 1986a, b).

Occurrences of gahnite are recorded from hydrothermally altered felsic volcanic rock of
Banskhapa-Pipariya, Koparpani and Muariya base metal prospects (Ghosh et al 2006). At BanskhapaPipariya prospect (figure 1), gahnite occurs in both the $\mathrm{Mg}-\mathrm{Ca}$ and the Fe-Al alteration zones. In the Fe-Al alteration zone, gahnite occurs in the assemblage quartz + gahnite + sericite \pm garnet \pm staurolite (figure $2 \mathrm{~B}$ ) occurring as conformable zones with the ore body and crops out impersistently for nearly $500 \mathrm{~m}$ along strike. The $\mathrm{Mg}-\mathrm{Ca}$ alteration zones occurring as lenses within the more widespread $\mathrm{Fe}-\mathrm{Al}$ alteration zone also host abundant gahnite in an assemblage consisting of anthophyllite + gahnite + garnet + chlorite (figure 2C). In hand specimens, dark green euhedral crystals of gahnite (up to $1 \mathrm{~cm}$ length) together with anthophyllite constitute up to $50 \%$ of the rock (figure 2D). In the Koparpani prospect (figure 1), outcrops of gahnite bearing rock extend intermittently for nearly $600 \mathrm{~m}$ along strike adjacent to the mineralized horizon. Light green octahedral crystals and crystal fragments can be found in the soil over the altered rock and even in stream sediments $800 \mathrm{~m}$ away from the gahnite bearing outcrops. Gahnite in this prospect is present in an assemblage containing quartz + gahnite + garnet \pm staurolite. Gahnite occurs either as poikiloblastic grain replacing garnet (figure $3 \mathrm{~A}$ ) or at the core of the coronal garnet along with quartz (figure 3B). Recently, Ghosh and Praveen (2007) made a detailed study of the relationship between associated garnet, gahnite and staurolite from the Koparpani area and suggested that they formed in a single metamorphic regime of continuously decreasing growth kinetics. At the Muariya prospect (figure 1), outcrops of gahnite bearing rock are rare, however they have been found in the drill core closely associated with the mineralized zone. Large gahnite (up to $1.5 \mathrm{~cm}$ in length) crystals occur in association with anthophyllite, chlorite and quartz along with disseminations and veins of sphalerite, galena, chalcopyrite, pyrrhotite and pyrite. Gahnite generally contains inclusions of sulphides. At the Dehalwara prospect (figure 1), outcrops of quartz-gahnite-garnet-biotite-staurolite rock occur within the Fe-Al alteration zone towards the footwall side. Petrographic evidence is suggestive of gahnite formation from Zn-bearing biotite during its transformation to chlorite (figures 3C, D). At the Bhuyari prospect (figure 1), gahnite is present in the quartz + biotite + muscovite + plagioclase + gahnite + garnet + chlorite assemblage along with disseminated sulphides and is closely associated with the mineralized zone. Recently Praveen and Ghosh (2007) documented two generations of gahnite from the area where first generation gahnite formed by desulphidation process and sometimes contain inclusions of sphalerite and 


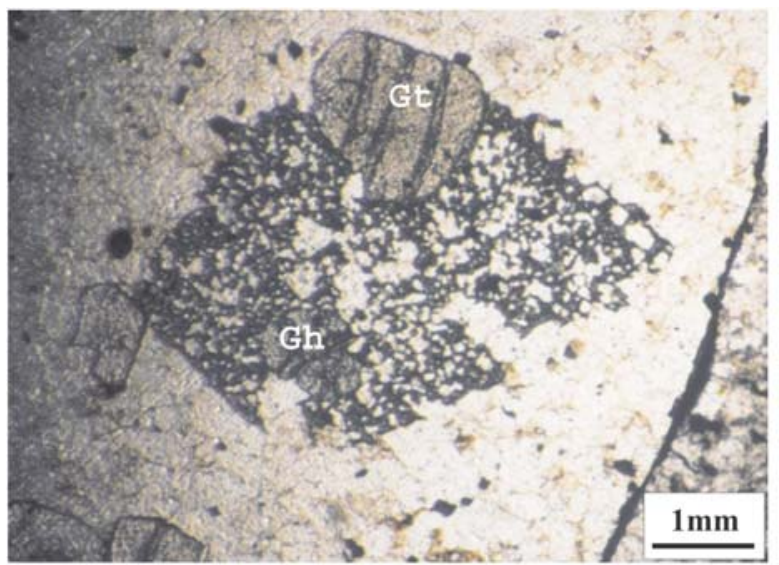

(A)

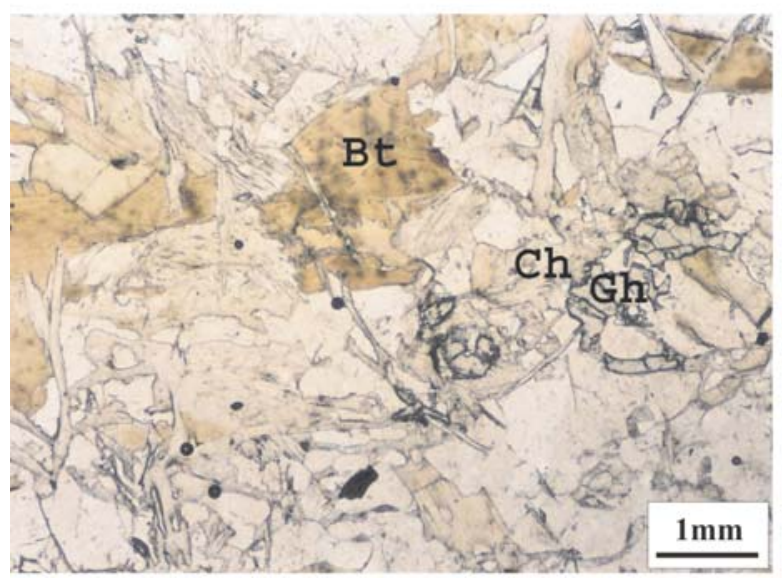

(C)

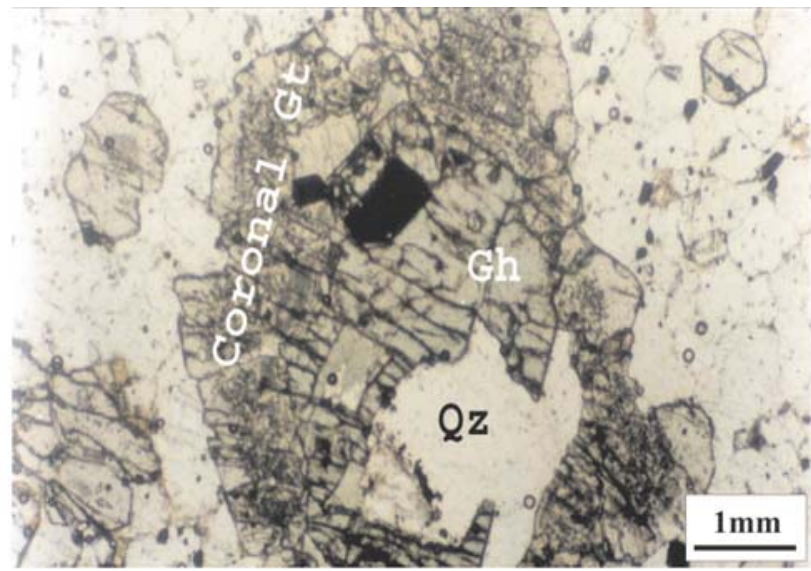

(B)

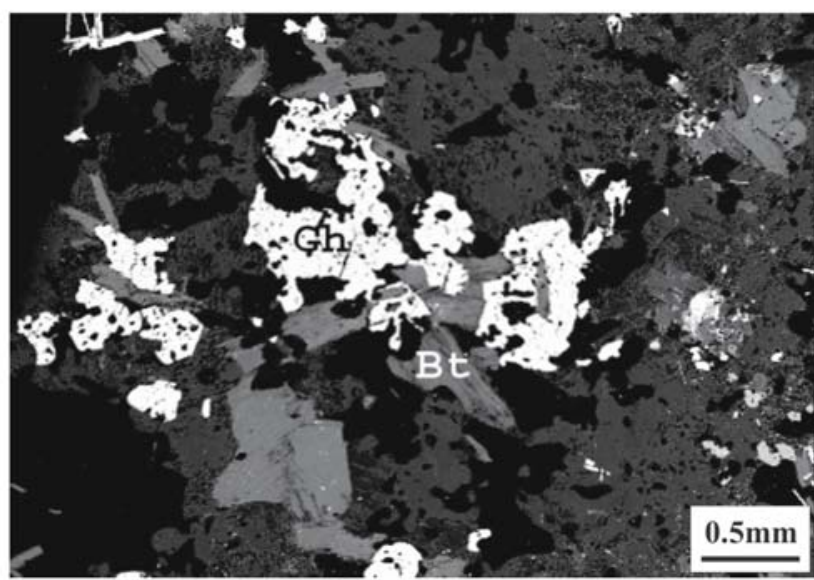

(D)

Figure 3. (A) Poikiloblastic gahnite (Gh) replacing garnet (Gt) from the Koparpani prospect; (B) Gahnite together with quartz $(\mathrm{Qz})$ occurring at the core of the coronal garnet from the same prospect; (C) Formation of gahnite from Zn-bearing biotite during the chloritisation process; (D) BSE picture of the same as in (C).

second generation gahnite formed by transformation from biotite and occur as pseudomorphs after biotite. At the Bhawra-Tekra prospect (figure 1), dark green gahnite is present in the anthophyllitechlorite bearing rocks.

From a study on the gahnite compositions from base metal sulphide occurrences, Colorado, Heimann et al (2005) postulated that the composition of zincian spinel in and around metamorphosed massive sulphide deposits is influenced by bulk rock composition which in the case of $\mathrm{Mg}$ rich alteration zones in Colorado causes a marked enrichment in the spinel component $\left(\mathrm{MgAl}_{2} \mathrm{O}_{4}\right)$ of zincian spinel. Present study on compositions of zincian spinel from different prospects of the Betul Belt does not corroborate their findings and it clearly shows that zincian spinel from both the alteration zone (Mg-rich and Al-rich) have similar restricted composition (table 1, figure 4).

\subsection{Zincian staurolite}

Like gahnite, zincian staurolite is also considered to be a potential exploration guide for massive sulphides (Huston and Patterson 1995; Sandhaus and Craig 1986). It has been documented in metamorphosed massive sulphide deposits, meta-exhalites, alteration zones (later metamorphosed) and also in meta-pelites. Zn is commonly partitioned into staurolite and stabilizes staurolite to the upper amphibolite grade (Spry and Scott 1986b). Spry and Scott (1986a) proposed that Zn content of staurolite might be a useful guide to metamorphosed sulphide ores. Zincian staurolite with greater than $5 \mathrm{wt} \% \mathrm{ZnO}$ (or approximately $>1 \mathrm{Zn}$ apfu) is an excellent indicator of close proximity to sulphides. Staurolites in sulfide bearing and sulfide free assemblages may contain up to $9 \mathrm{wt} \%$ ZnO (Spry and Scott 1986b; Spry 2000). Staurolite in massive sulfide deposits generally contains 


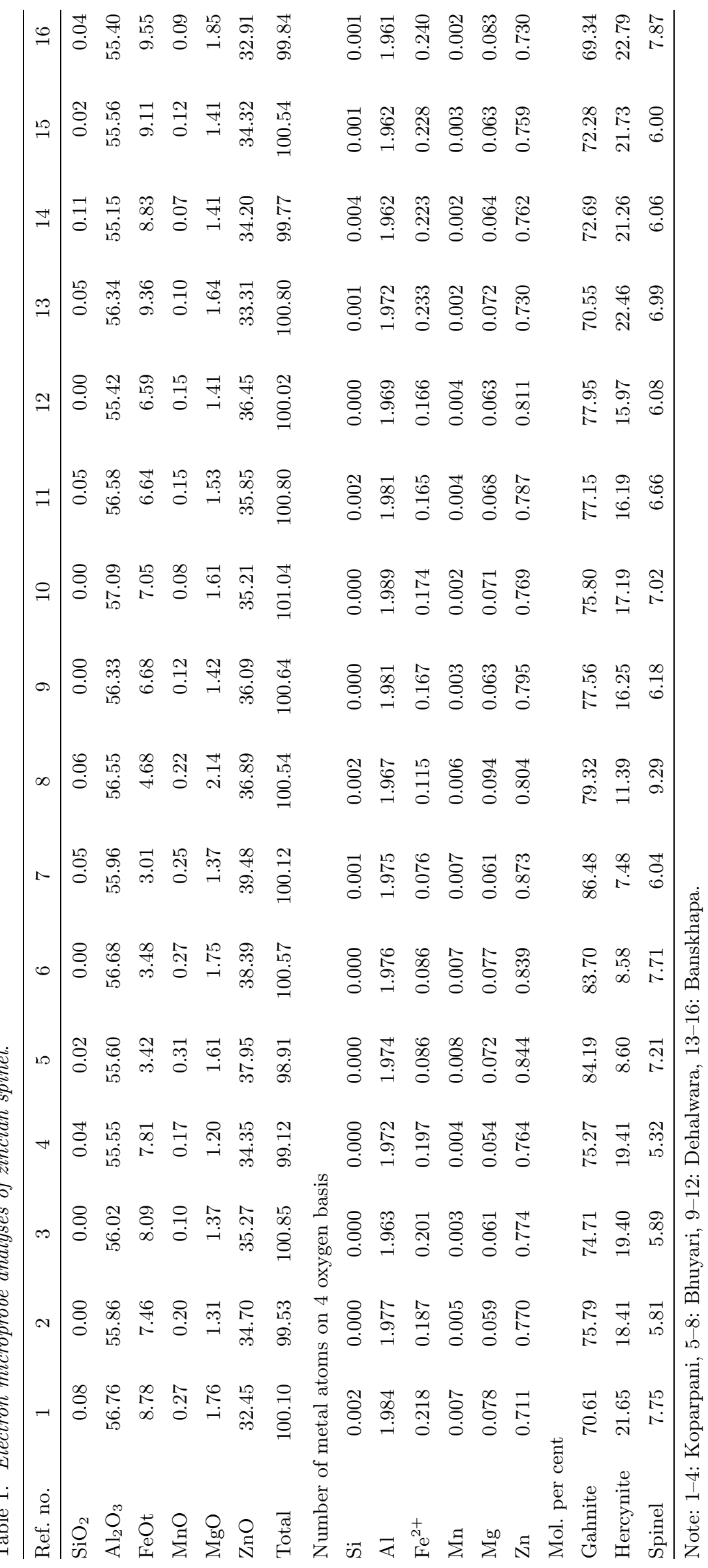




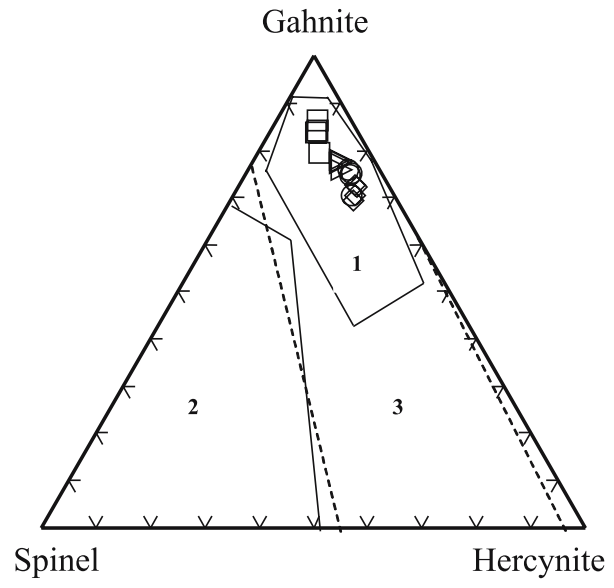

Figure 4. Triangular plot showing the compositions of zincian spinels from the Koparpani (circle), Bhuyari (square), Dehalwara (triangle) and Banskhapa (rhomb) prospects in terms of $\mathrm{ZnAl}_{2} \mathrm{O}_{4}-\mathrm{FeAl}_{2} \mathrm{O}_{4}-\mathrm{MgAl}_{2} \mathrm{O}_{4}$ contents. Compositional fields of spinels from metamorphosed massive sulfides in Fe-Al meta-sedimentary and meta-volcanic rocks (1), metamorphosed massive sulfide deposits and S-poor rocks in $\mathrm{Mg}-\mathrm{Ca}-\mathrm{Al}$ alteration zones (2) and unaltered and hydrothermally altered $\mathrm{Fe}-\mathrm{Al}$ rich meta-sedimentary and meta-volcanic rocks (3) of worldwide localities are superimposed (after Heimann et al 2005).

4-9 wt\% ZnO whereas they contain 0-7 wt\% $\mathrm{ZnO}$ in the alteration zones (Spry et al 2000). Spry and Scott (1986b) have shown that staurolite formed by desulfidation of sulfides in the Appalachians and Scandinavian Caledonides contain higher $\mathrm{ZnO}$ $(\sim 7-9 \mathrm{wt} \%)$ than those that did not form by desulfidation mechanism $(\sim 6 \mathrm{wt} \% \mathrm{ZnO})$ as in Broken Hill, Australia, Gamsberg, South Africa and Geco, Ontario.

In Betul Belt, staurolite is an ubiquitous mineral in the Al-Fe alteration zones in all the prospects. At the Banskhapa-Pipariya, Bhuyari, Bhawra-Tekra and Koparpani prospects (figure 1), it occurs in an assemblage consisting of quartz, muscovite, biotite, garnet and sometimes gahnite, where staurolite could attain a length of $3 \mathrm{~cm}$. At Muariya (figure 1), staurolite bearing rocks are rarely present in the outcrop, however staurolite crystals are found in the coarse stream sediments around the prospect and also found in drill core, where it occurs in a quartz + biotite + garnet + staurolite + sericite assemblage (figure 5A). Zincian staurolite occurs either as poikiloblastic grain replacing zincian spinel (figure 5B) or as discrete grains possibly formed by desulphidation process (figure 5C). Mineral composition data from the Koparpani and Banskhapa area are furnished in table 2. Staurolite of Koparpani area contains 5.0 to $6.5 \mathrm{wt} \% \mathrm{ZnO}$ whereas that of Banskhapa area contains 7.0 to $8.2 \mathrm{wt} \% \mathrm{ZnO}$ (table 2). It is suggested that zincian staurolites of Koparpani area might have formed at the expense of gahnite in a retrograde environment but that of Banskhapa area could be a desulphidation product.

\section{$3.3 \mathrm{Zn}$-bearing biotite}

Little is known about the behaviour of $\mathrm{Zn}$ in biotite. The highest zinc content of granitic biotite reported so far is $1920 \mathrm{ppm}$ (Bray 1942) whereas that of metamorphic biotites from MMS deposits is $5350 \mathrm{ppm}$ from Broken Hill, Australia. Because of its crystallographic character biotite cannot contain much $\mathrm{Zn}$ in its structure. Therefore, Zn-bearing biotite could be relatively rare and biotite with any amount of $\mathrm{ZnO}$ can be used as a key mineral in exploration.

In Betul Belt Zn-bearing biotite is found to be intimately associated with the gahnite near the ore zones. It has been reported from the quartzbiotite-plagioclase-garnet-gahnite rock from the Bhuyari prospect (Praveen and Ghosh 2007). At the Dehalwara prospect (figure 1) Zn-bearing biotite occurs in association with gahnite with coexisting chlorite and garnet and contains highest $\mathrm{ZnO}(0.62 \mathrm{wt} \%$ ) (table 3$)$.

\subsection{Zincian ilmenite}

Ecandrewsite $\left(\mathrm{ZnTiO}_{3}\right)$, the zinc analogue of ilmenite was first described from the north mine at Broken Hill, New South Wales, Australia by Brown et al (1970) and was discovered subsequently from the nearby Melbourne Rockwell mine at Little Broken Hill by Birch et al (1982 and 1988). Zincian ilmenite-ecandrewsite solid solution is not very common in nature. There are only two known occurrences of zincian ilmenite-ecandrewsite solid solutions from regionally metamorphosed metalliferous sedimentary rocks (Broken Hill, Australia and Death Valley, California). The association of gahnite with ilmenite is common but gahnite coexisting with zincian ilmenite-ecandrewsite is only reported from Broken Hill, Australia (Birch et al 1988; Plimer 1990) and Koparpani, Betul Belt, central India (Ghosh and Praveen 2007). Besides Broken Hill and Little Broken Hill, Australia, the ecandrewsite at Koparpani is the third reported occurrence spatially associated with metamorphosed massive sulphide deposits.

Zincian ilmenite occurs as an accessory mineral in the alteration zone assemblages and is found in association with gahnite, garnet, biotite and sericite. At Koparpani, ilmenite-ecandrewsite occurs as discrete grains in the intensely altered quartz + garnet + gahnite assemblages. There are two distinct populations of ilmenite-ecandrewsite solid solution. The first population consists of relatively coarser, euhedral grains of ilmenite present 


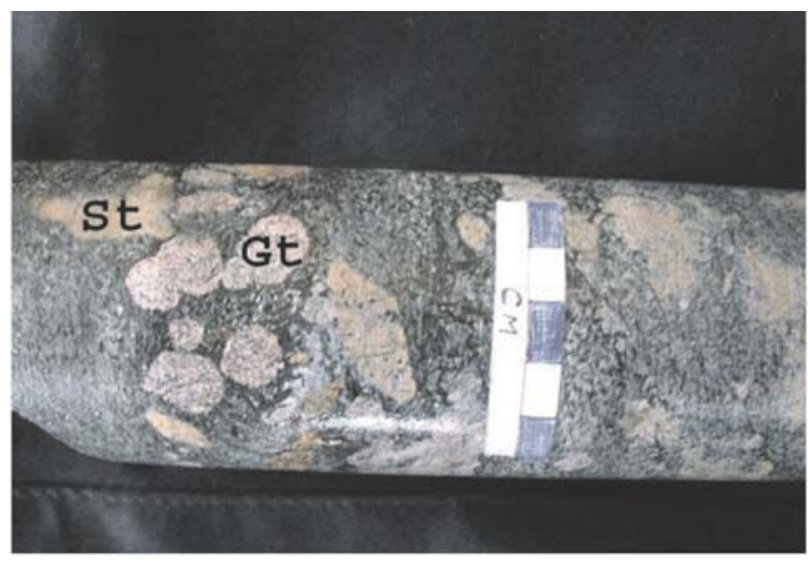

(A)

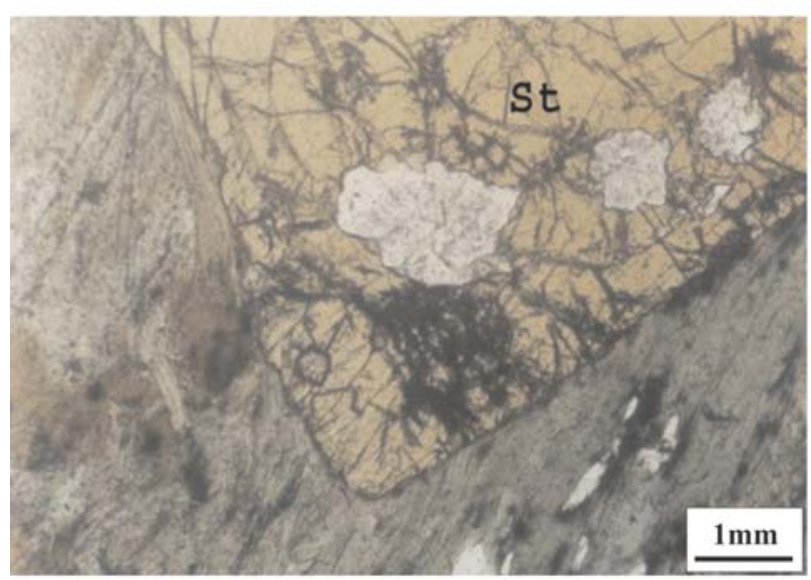

(C)

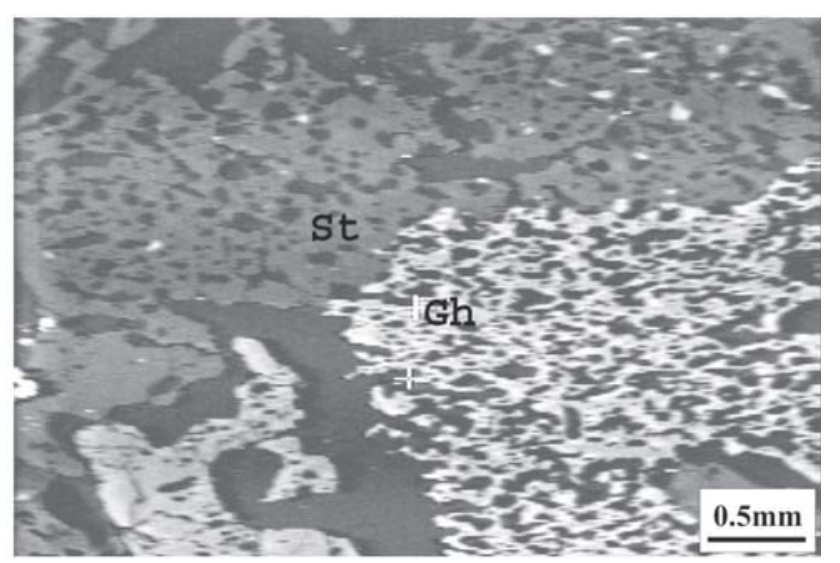

(B)

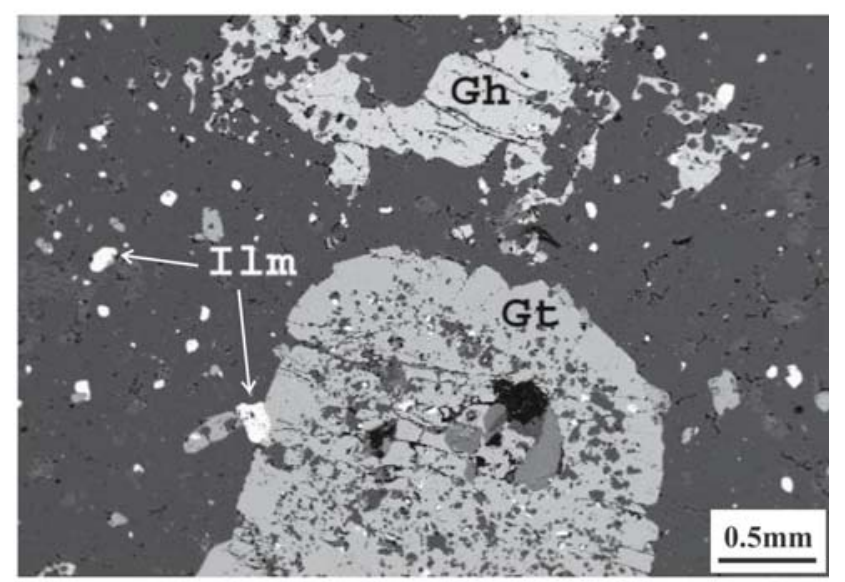

(D)

Figure 5. (A) Drill core from Muariya prospect showing garnet and staurolite porphyroblasts; (B) BSE picture showing formation of zincian staurolite (St) at the expense of gahnite (Gh); (C) Discrete euhedral grain of zincian staurolite; (D) BSE picture showing zincian ilmenite in matrix as well as tiny inclusions within gahnite and garnet (Gt).

in the matrix whereas, the second population consists of tiny grains and blebs of ilmenite occurring as inclusions within garnet and gahnite (figure 5D). Zincian ilmenite (with $<4 \mathrm{wt} \% \mathrm{ZnO}$ ) inclusions within garnet and gahnite also occurs at the Banskhapa and Dehalwara prospects. Ilmenite compositions in these two prospects along with Koparpani have been presented in table 4 and plotted in terms of $\mathrm{Zn}, \mathrm{Mn}$ and Fe mole proportion (figure 6). Since geikielite does not occur as a major component (maximum 0.011 apfu $\mathrm{Mg}$ ), $\mathrm{Mg}$ has been excluded.

\section{Discussion}

Zincian spinel $\left[(\mathrm{Zn}, \mathrm{Fe}, \mathrm{Mg}) \mathrm{Al}_{2} \mathrm{O}_{4}\right]$ occurs in various geologic settings but is most commonly associated with metamorphosed massive sulphide deposits (Heimann et al 2005). Textural, experimental and thermodynamic studies suggest that zincian spinel can form in multiple ways including:
- metamorphism of Zn-oxide phases (Segnit 1961),

- desulphidation of sphalerite during metamorphism (Sangster and Scott 1976),

- precipitation from a metamorphic hydrothermal solution (Wall 1977) and

- breakdown of zinc-bearing silicates such as staurolite (Stoddard 1979) and biotite (Atkin 1978; Dietvorst 1980) during metamorphism.

Calculations of $\mathrm{fo}_{2}-\mathrm{fS}_{2}$ relations in the system Zn-Fe-Al-Si-S-O by Wall and England (1979) suggest that sphalerite and almandine react to form gahnite, quartz and Fe sulphide at low $\mathrm{fo}_{2}$ and $\mathrm{fs}_{2}$ values by the following reactions:

$\left[\mathrm{Fe}_{3} \mathrm{Al}_{2} \mathrm{Si}_{3} \mathrm{O}_{12}\right]$ in garnet

$+[\mathrm{ZnS}]$ in sphalerite $+2.5 \mathrm{~S}_{2}$

$=\left[\mathrm{ZnAl}_{2} \mathrm{O}_{4}\right]$ in spinel $+3 \mathrm{FeS}_{2}+3 \mathrm{SiO}_{2}+\mathrm{O}_{2}$, 


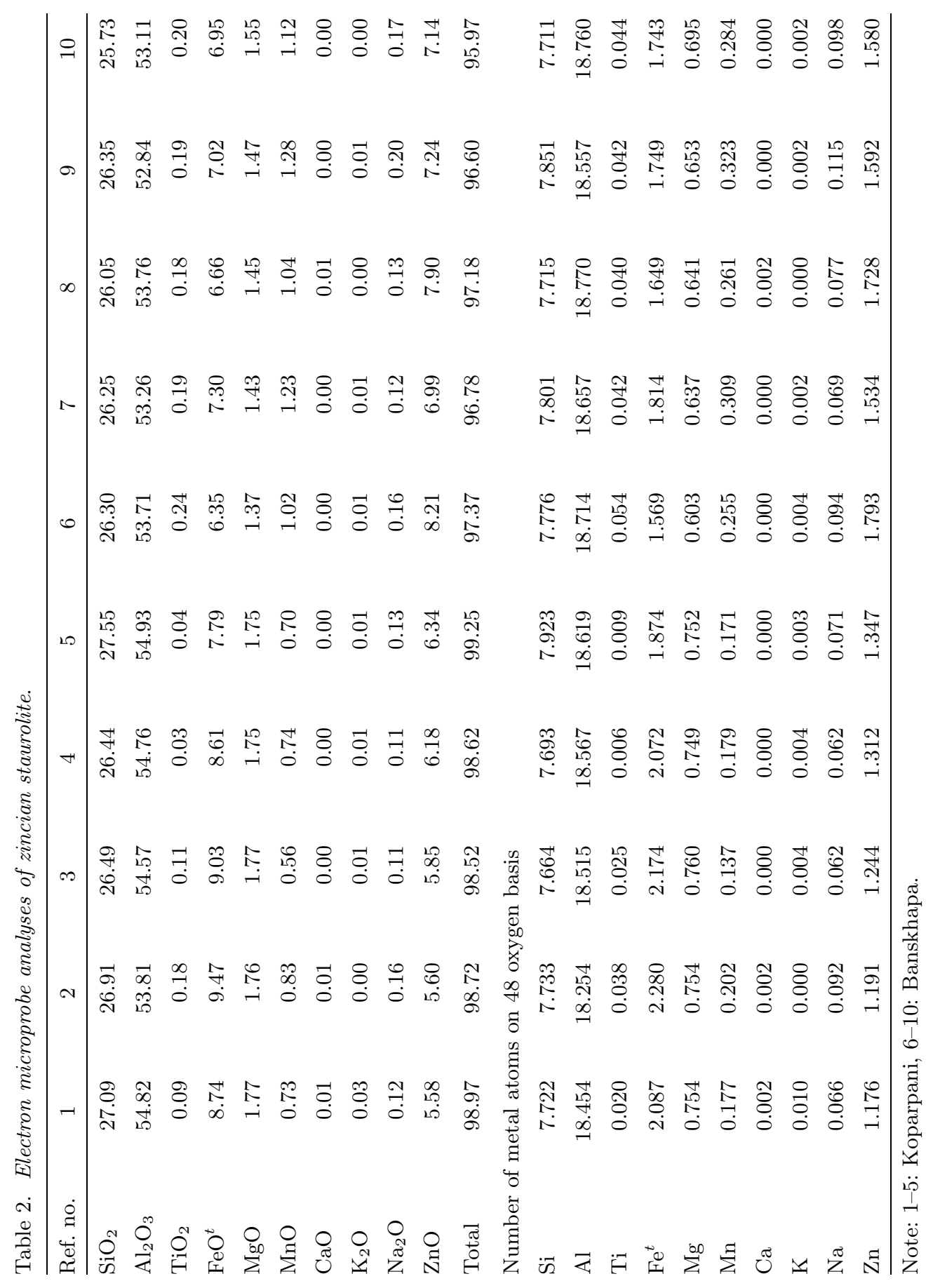




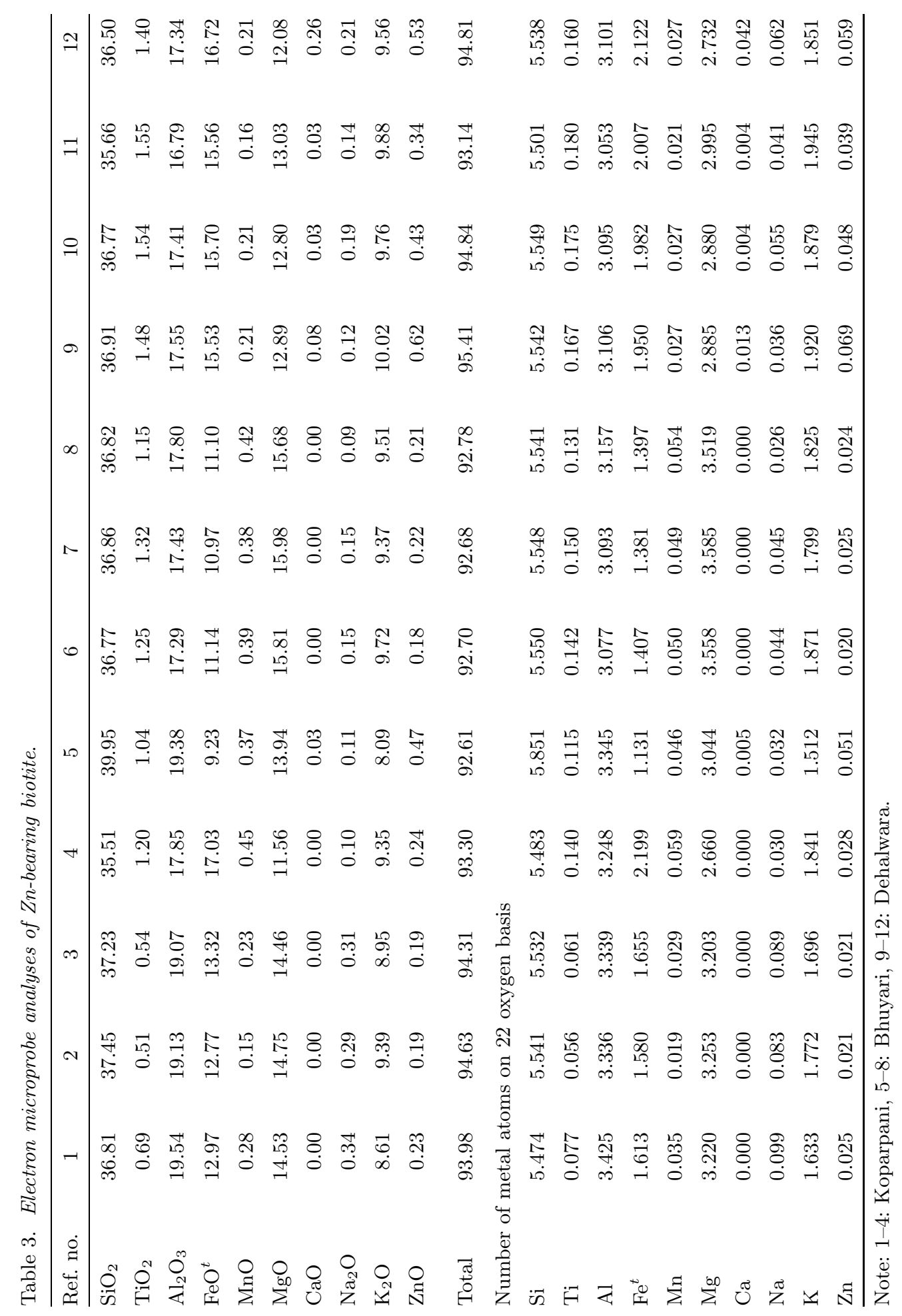




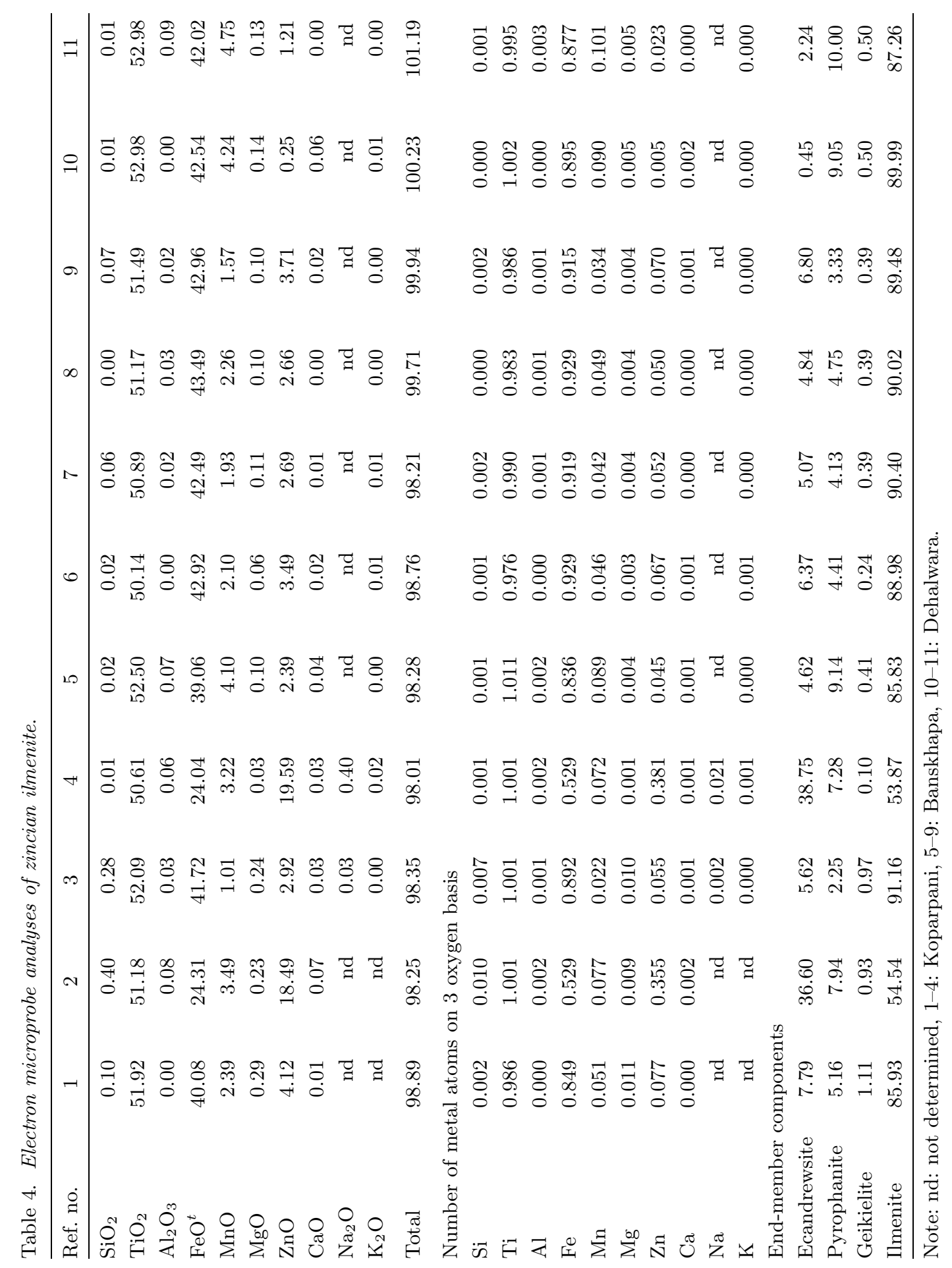




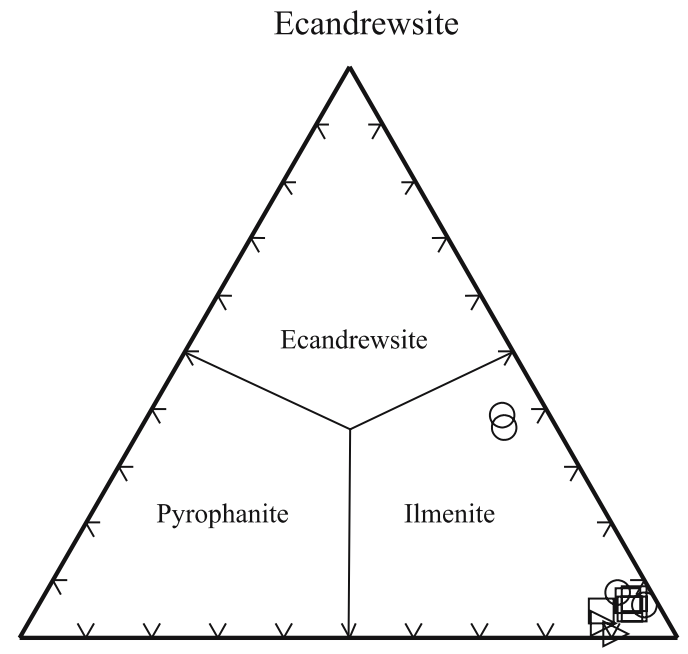

Pyrophanite

Ilmenite

Figure 6. Zn-Fe-Mn molar proportions in zincian ilmenite from Koparpani (circle), Banskhapa (square) and Dehalwara (triangle) prospects.

$\left[\mathrm{Fe}_{3} \mathrm{Al}_{2} \mathrm{Si}_{3} \mathrm{O}_{12}\right]$ in garnet $+[\mathrm{ZnS}]$ in sphalerite $+\mathrm{S}_{2}$

$$
=\left[\mathrm{ZnAl}_{2} \mathrm{O}_{4}\right] \text { in spinel }+3 \mathrm{FeS}+3 \mathrm{SiO}_{2}+\mathrm{O}_{2},
$$

whereas sphalerite and aluminosilicate (sillimanite) react to form gahnite at high $\mathrm{fo}_{2}$ and $\mathrm{fs}_{2}$ values by the following reactions:

$[\mathrm{ZnS}]$ in sphalerite $+\mathrm{FeS}_{2}+2 \mathrm{Al}_{2} \mathrm{SiO}_{5}+\mathrm{O}_{2}$

$=\left[\mathrm{ZnAl}_{2} \mathrm{O}_{4}\right]$ in spinel $+\left[\mathrm{FeAl}_{2} \mathrm{O}_{4}\right]$ in spinel

$$
+2 \mathrm{SiO}_{2}+\frac{3}{2} \mathrm{~S}_{2}
$$

$$
\begin{aligned}
& {[\mathrm{ZnS}] \text { in sphalerite }+\mathrm{FeS}+2 \mathrm{Al}_{2} \mathrm{SiO}_{5}+\mathrm{O}_{2}} \\
& =\left[\mathrm{ZnAl}_{2} \mathrm{O}_{4}\right] \text { in spinel }+\left[\mathrm{FeAl}_{2} \mathrm{O}_{4}\right] \text { in spinel } \\
& \quad+2 \mathrm{SiO}_{2}+\mathrm{S}_{2} .
\end{aligned}
$$

Experimental work carried out by Spry and Scott (1986a) also corroborated earlier suggestions by Sangster and Scott (1976) that zincian spinel may be a product of desulphidation of sphalerite. They have also suggested that spinel in sulphide deposits has a restricted gahnite to hercynite ratio in comparison to, for example, spinel from aluminous metasediments. Spinel although commonly distributed throughout massive sulphide deposits, it is mostly found near their margins probably because higher alumina is likely to be encountered there. Since gahnites of Betul Belt have a narrow range of composition and the plots fall well within the field of metamorphosed massive sulphides (figure 4), it can be suggested that gahnites of Betul Belt are a product of desulphidation of sphalerite during metamorphism involving either garnet or sillimanite.

Further support for the participation of desulphidation mechanisms involving sphalerite in the formation of zincian spinel in Betul Belt comes from the mantling of sphalerite by zincian spinel and the presence of a fine dusting of sphalerite inclusions in gahnite at Bhuyari and Koparpani. Although desulphidation of sphalerite involving either garnet or sillimanite was responsible for the formation of zincian spinel in most areas, it is also likely that other desulphidation reactions such as involving anthophyllite occurred in some of the prospects like Banskhapa and Bhanwra-Tekra. The presence of stable equilibrium assemblage, wide scale retrograde overprinting and absence of reaction textures does not allow for the unequivocal identification of such reactions. However, formation of zincian spinel other than by desulphidation such as breakdown of Zn-bearing biotite is evidenced from the Bhuyari and Dehalwara prospects. Praveen and Ghosh (2007) documented the presence of chloritised biotite near the nucleation point of gahnite. They have also observed the decrease in zinc content of biotite with increasing proximity to gahnite. From these observations it was suggested that zinc was released from Zn-rich biotite to form gahnite and this may happen if the zinc saturation limit of biotite is overstepped by biotite consuming reactions to form chlorite during retrograde metamorphism.

In MMS deposits of amphibolite grade metamorphism, zincian staurolite can either form (1) from sphalerite by desulphidation process (Spry and Scott 1986b) or (2) from gahnite (Atkin 1978; Spry 1982; Moore and Reid 1989) by the following reactions:

$2[\mathrm{ZnS}]$ in sphalerite $+2[\mathrm{FeS}]$ in pyrrhotite

$$
\begin{aligned}
& +9 \mathrm{Al}_{2} \mathrm{SiO}_{5}+\mathrm{H}_{2} \mathrm{O}+2 \mathrm{O}_{2} \\
= & {\left[\mathrm{Zn}_{2} \mathrm{Al}_{9} \mathrm{Si}_{4} \mathrm{O}_{23}(\mathrm{OH})\right] \text { in staurolite } } \\
& +\left[\mathrm{Fe}_{2} \mathrm{Al}_{9} \mathrm{Si}_{4} \mathrm{O}_{23}(\mathrm{OH})\right] \text { in staurolite } \\
& +\mathrm{SiO}_{2}+2 \mathrm{~S}_{2} .
\end{aligned}
$$



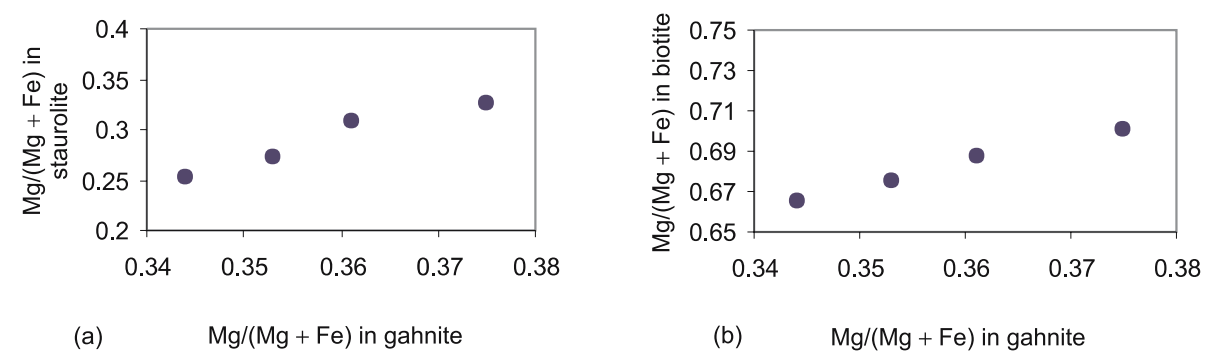

Figure 7. Plot showing a positive correlation of $\mathrm{Mg} /(\mathrm{Mg}+\mathrm{Fe})$ ratio of (a) staurolite versus gahnite and (b) biotite versus gahnite.

$2\left[\mathrm{ZnAl}_{2} \mathrm{O}_{4}\right]$ in spinel $+2\left[\mathrm{FeAl}_{2} \mathrm{O}_{4}\right]$ in spinel

$$
\begin{aligned}
& +3 \mathrm{SiO}_{2}+5 \mathrm{Al}_{2} \mathrm{SiO}_{5}+\mathrm{H}_{2} \mathrm{O} \\
= & {\left[\mathrm{Zn}_{2} \mathrm{Al}_{9} \mathrm{Si}_{4} \mathrm{O}_{23}(\mathrm{OH})\right] \text { in staurolite } } \\
& +\left[\mathrm{Fe}_{2} \mathrm{Al}_{9} \mathrm{Si}_{4} \mathrm{O}_{23}(\mathrm{OH})\right] \text { in staurolite. }
\end{aligned}
$$

Although equilibrium coexistence between staurolite and gahnite exists in most of the outcrop of Koparpani prospect, considering all the body of petrographic and chemical evidence such as close spatial association of zincian staurolite and gahnite, poorly defined contact relationship, presence of gahnite ghosts within staurolite, rugged appearance of gahnite and comparable $\mathrm{Zn}$ contents to those that did not form by desulphidation processes, it is suggested that zincian staurolites of Koparpani area at places show evidences of formation at the expense of gahnite by retrogression. Formation of zinc-rich staurolite from the breakdown of second generation gahnite might have formed by the following schematic reaction:

$$
\begin{aligned}
& \text { Almandine }+ \text { Gahnite }+ \text { K-feldspar }+ \text { water } \\
& =\text { Zincian staurolite }+ \text { Zn bearing biotite } \\
& \quad+\text { Quartz. }
\end{aligned}
$$

Reaction (7) could only occur where little K-feldspar was present (Stoddard 1979). A plot of $\mathrm{Mg} /(\mathrm{Mg}+\mathrm{Fe})$ ratios in coexisting staurolite, biotite and gahnite gives a distinct correlation (figure 7) and it is therefore suggested that the $\mathrm{Fe}$ and $\mathrm{Mg}$ contents of staurolite and biotite are controlled by coexisting gahnite.

Textural, experimental and thermodynamic studies suggest that zincian ilmenite can form in several means including (1) reaction between ilmenite and zincian clays or carbonates during prograde metamorphism (Plimer 1990), (2) desulphidation of sphalerite or by breakdown of zinc bearing minerals such as staurolite, biotite and hogbomite (Whitney et al 1993), (3) direct precipitation from hydrothermal solution in some vugs as reported from Fuzhau, China (Suwa et al 1987) and (4) subsolidus reaction of deuteric fluids with the primary magmatic minerals (Mitchell and Liferovich 2004).

Assuming Fe-Zn mixing in ilmenite and spinel solid solutions as ideal, Whitney et al (1993) suggested the $\mathrm{Zn}-\mathrm{Fe}$ exchange equilibrium between ilmenite and spinel by the following reaction:

$$
\mathrm{ZnTiO}_{3}+\mathrm{FeAl}_{2} \mathrm{O}_{4}=\mathrm{FeTiO}_{3}+\mathrm{ZnAl}_{2} \mathrm{O}_{4}
$$

and calculated the distribution isotherms for $\mathrm{Zn}-\mathrm{Fe}$ exchange between ilmenite and gahnite using thermodynamic data. Using the distribution isotherms (as given by Whitney et al 1993) Ghosh and Praveen (2007) clearly demonstrated that there may not be any genetic link between gahnite and zincian ilmenite of the Koparpani prospect.

Although there is lack of petrographic evidence regarding the formation of zincian ilmenite, intimate association of this mineral with gahnite presumes that zincian ilmenite in the Betul Belt might have formed together with gahnite by desulphidation process. Ilmenite because of its tiny size commonly occurs as inclusions within gahnite.

\section{Conclusions}

$\mathrm{Zn}-\mathrm{Pb}-\mathrm{Cu}$ mineralisation in Betul Belt is volcanichosted where ore bodies formed either as exhalations on the sea-floor or as subsea-floor replacements or one involving both the processes. The ore zones are intimately associated with zones of intensely altered and metamorphosed felsic volcanic rock which also include lithologies resembling meta-exhalites (Ghosh and Praveen 2007). 
Field identification of such lithologies assumes great importance in exploration for base metal sulphides in the area. Minerals like staurolite, biotite and ilmenite are common in metamorphosed alteration zones and these zones are some times widespread, however, the use of in situ microbeam techniques like electron probe micro-analysis (EPMA) in the study of alteration zone samples can help to identify the Zn-bearing minerals and thereby narrow down on the more important orerelated alteration assemblages. Like in other metamorphosed massive sulphide deposits worldwide, these minerals are developed close to the mineralized horizon in Betul Belt. Gahnite and staurolite being resistant minerals are often found in stream sediments, soil apart from outcrop. Gahnites from Betul Belt have a very restricted range in composition (Gahnite ${ }_{69-86}$ Hercynite $_{7-23}$ spinel $_{5-9}$ ) and therefore the very presence of gahnite may indicate proximity to zinc mineralization. Staurolite compositions from soil, stream sediments and outcrop can also be used as a reliable guide to zinc mineralization in the absence of gahnite or along with gahnite. Ilmenite and biotite compositions can be used on outcrop samples of alteration zones to target potential mineralized zones. Petrographic identification of these minerals has immense exploration significance as presence of some of these minerals in soil or stream sediment can be used to locate new areas for mineralization. Presence of these minerals in outcrops can supplement geochemical and geophysical data during exploration stage and can help in identifying target areas for drilling as these minerals act as direct vectors to ore.

\section{Acknowledgements}

Authors wish to express their gratitude to Dr. A Roy, Deputy Director General and Dr. Utpal Chakrabarty, Director, Geological Survey of India (GSI), Kolkata for their encouragement and overall guidance. Mr. H S Shrivastava is gratefully acknowledged for providing many hours of stimulating discussion. Dr. N C Pant, Dr. A Kundu and Ms. S Joshi of EPMA Lab., GSI, Faridabad and Mr. B Chattopadhyay and Dr. S Sengupta of EPMA Lab., Central Petrological Laboratory, GSI, Kolkata are sincerely thanked for assistance with the microprobe analysis. Special thanks go to Dr. P G Spry, Iowa State University, USA for providing some invaluable reprints.

\section{References}

Atkin B P 1978 Hercynite as a breakdown product of staurolite from within the aureole of Ardara Pluton. Co. Donegal, Fire; Min. Mag. 42 237-239.
Birch W D, Chapman A and Pecover S R 1982 Minerals of Broken Hill; In: The minerals (eds) Worner H K and Mitchell R (Austr. Min. Smelting Ltd, Melbourne) 68-195.

Birch W D, Burke E A J, Wall V J and Etheridge M A 1988 Ecandrewsite, the zinc analogue of ilmenite, from Little Broken Hill, New South Wales, Australia, and the San Valentine mine, Sierra de Cartegena, Spain; Min. Mag. 52 237-240.

Brown R N, Riley J F and Schultz R K 1970 A new zinc bearing ilmenite from Broken Hill, Contribution to Australia Mineralogy; Austr. Min. Dev. Lab. Bull. 10 $48-50$.

Dietvorst E J L 1980 Biotite breakdown and the formation of gahnite in metapelitic rocks from Kemio, Southwest Finland; Contrib. Min. Pet. 75 327-337.

Doyle M G and Allen R L 2003 Subsea-floor replacement in Volcanic-hosted massive sulphide deposits; Ore Geol. Rev. 23 183-222.

Franklin J M, Lyden J W and Sangster D F 1981 Volcanic associated massive sulphide deposits; Econ. Geol. $75^{\text {th }}$ Anniversary Volume 485-627.

Ghosh B, Shrivastava H S, Praveen M N, Kumaran G S and Sisodiya D S 2003 Occurrence and genetic implication of gahnite from Betul Belt, Madhya Pradesh; Gond. Geol. Mag. 18 108-115.

Ghosh B, Praveen M N and Shrivastava H S 2006 Gahnite chemistry from metamorphosed $\mathrm{Zn}-\mathrm{Pb}-\mathrm{Cu}$ sulphide occurrences of Betul Belt, Central India; Geol. Soc. India 67 17-20.

Ghosh B and Praveen M N 2007 Garnet-Gahnite-Staurolite relations and occurrence of Ecandrewsite from the Koparpani base metal sulfide prospect, Betul Belt, Central India; Neues Jahr. fur Min. Abhand. $\mathbf{1 8 4}$ $105-116$.

Heimann A, Spry P G and Teale G S 2005 Zincian spinel associated with metamorphosed Proterozoic base-metal sulfide occurrences, Colorado: A re-evaluation of gahnite composition as a guide in exploration; Can. Min. 43 601-622.

Huston D L and Patterson D J 1995 Zincian staurolite in the Dry River South volcanic-hosted massive sulphide deposit, northern Queensland, Australia: An assessment of its usefulness in exploration; Appl. Geochem. 10 329-336.

Mahakud S P, Raut P K, Hansda C, Ramteke P F, Chakraborty U, Praveen M N and Sisodiya D S 2001 Sulphide mineralisation in the central part of Betul Belt around Ghisi-Muariya-Koparpani area, Betul district, Madhya Pradesh; Geol. Surv. India Spec. Publ. 64 377-385.

Mahakud S P, Hansda C, Raut P K and Ramteke P F 2002 Final report on detailed exploration of base metal mineralisation in Banskhapa-Pipariya block, Betul district, M.P.; Geol. Surv. India (unpublished progress report).

McClenaghan M B 2005 Indicator mineral methods in mineral exploration; Geochemistry: Exploration, Environment, Analysis 5 233-245.

Mitchell R H and Liferovich R P 2004 Ecandrewsite-Zincian pyrophanite from Lujavrite, Pilansberg alkaline complex, South Africa; Can. Min. 42 1169-1178.

Moore J M and Reid A M 1989 A Pan-African zincian staurolite imprint on Namaqua quartz-gahnite-sillimanite assemblages; Min. Mag. 53 63-70.

Plimer I R 1990 The ilmenite-ecandrewsite solid solution series, Broken Hill, Australia; Neues Jahrb. Mineral Monatsh 12 529-536.

Praveen M N, Ghosh B, Shrivastava H S, Kumaran G S, Roy S and Sisodiya D S 2005 Metamorphic mineral 
assemblages associated with sulphide mineralisation in Betul Belt: A possible hydrothermal origin. In: Proceeding volume of $1^{\text {st }}$ Indian Mineral Congress "Showcasing the Indian Mineral Industry in the $21^{\text {st }}$ Century", ISM, Dhanbad, India (eds) Sinha A and Singh S K (New Delhi: Allied Publishers) 193-218.

Praveen M N and Ghosh B 2007 Multiple origins of gahnite associated with hydrothermal alteration from the Bhuyari base metal prospect of Proterozoic Betul Belt, Central India; Geol. Soc. India 69 233-241.

Praveen M N, Ghosh B, Shrivastava H S, Dora M L and Gaikwad L D 2007 Sulphide mineralization in Betul Belt: Classification and general characteristics; Geol. Soc. India 69 85-91.

Riverin G and Hodgson C J 1980 Wall-rock alteration at the Millenbach $\mathrm{Cu}-\mathrm{Zn}$ mine, Noranda, Quebec; Econ. Geol. 75 424-444.

Roy A and Prasad M H 2001 Precambrian of central India: a possible tectonic model; Geol. Surv. India Spec. Publ. 64 177-197.

Roy A and Prasad M H 2003 Tectonothermal events in Central Indian Tectonic Zone (CITZ) and its implications in Rodinian crustal assembly; J. Asian Earth Sci. 22 115-129.

Sandhaus D J and Craig J R 1986 Gahnite in the metamorphosed stratiform massive sulfide deposits of the Mineral district, Virginia, U.S.A; Tsch. Min. Petro. Mitt. 35 $77-98$.

Sangster D F and Scott S D 1976 Precambrian massive Cu$\mathrm{Zn}-\mathrm{Pb}$ sulfide ores of North America; In: Handbook of strata-bound and stratiform ore deposits (ed.) Wolf K H (Amsterdam: Elsevier) 6 129-222.

Segnit E R 1961 Petrology of the zinc lode, New Broken Hill Consolidated Ltd., Broken Hill; Aust. Inst. Min. Metall. Proc. 199 87-112.
Sheridan D M and Raymond W H 1984 Precambrian deposits of zinc-copper-lead sulfides and zinc spinel (gahnite) in Colorado; US Geol. Surv. Bull. 1550p.

Spry P G 1982 An unusual gahnite forming reaction, Geco base metal deposit, Manitouwadge, Ontario; Can. Min. 20 549-553.

Spry P G 2000 Sulfidation and oxidation haloes as guides in the exploration for metamorphosed massive sulfide deposits; Review Econ. Geol. 11 149-161.

Spry P G and Scott S D 1986a The stability of zincian spinels in sulfide systems and their potential as exploration guides for metamorphosed massive sulfide deposits; Econ. Geol. 81 1446-1463.

Spry P G and Scott S D 1986b Zincian spinel and staurolite as guides to ore in the Appalachians and Scandinavian Caledonides; Can. Min. 24 147-163.

Spry P G, Peter J M and Slack J F 2000 Meta-exhalites as exploration guides to ore; Review Econ. Geol. 11 163-201.

Stoddard E F 1979 Zinc-rich hercynite in high grade metamorphic rocks: a product of the dehydration of staurolite; Amer. Min. 64 736-741.

Suwa K, Enami M, Hiraiwa I and Yang T 1987 Zn-Mn ilmenite in the Kuiqi Granite from Fuzhou, Fujian Province, East China; Min. Pet. 36 111-120.

Wall V J 1977 Non-sulphide zinc bearing phases and the behaviour of zinc during metamorphism; $2^{\text {nd }}$ Aust. Geol. Conv. Abst., 70p.

Wall V J and England R N 1979 Zn-Fe spinel-silicate-sulfide reactions as sensors of metamorphic intensive variables and processes; Geol. Soc. Amer. Abst. Prog. 11 354p.

Whitney D L, Hirschmann M and Miller M G 1993 Zincian ilmenite-Ecandrewsite from a pelitic schist, Death Valley, California, and the paragenesis of $(\mathrm{Zn}, \mathrm{Fe}) \mathrm{TiO}_{3}$ solid solution in metamorphic rocks; Can. Min. 31 425-436. 